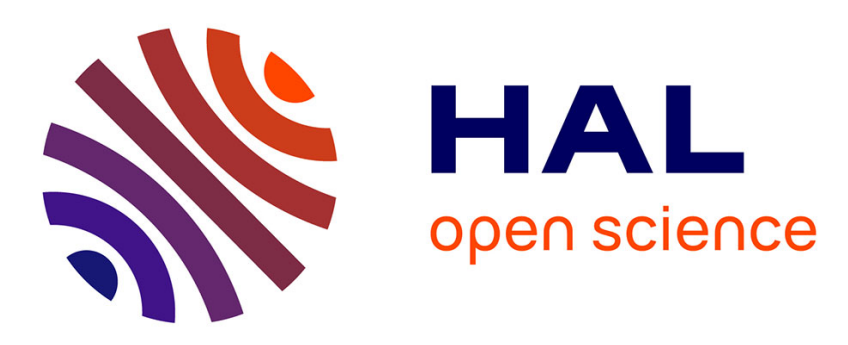

\title{
Cetylpyridinium removal using phosphate-assisted electrocoagulation, electroreduction and adsorption on electrogenerated sorbents
}

Abdenacer Flilissa, Philippe Méléard, André Darchen

\section{To cite this version:}

Abdenacer Flilissa, Philippe Méléard, André Darchen. Cetylpyridinium removal using phosphateassisted electrocoagulation, electroreduction and adsorption on electrogenerated sorbents. Chemical Engineering Journal, 2016, 284, pp.823-830. 10.1016/j.cej.2015.08.135 . hal-01198730

HAL Id: hal-01198730

https://hal-univ-rennes1.archives-ouvertes.fr/hal-01198730

Submitted on 3 Dec 2015

HAL is a multi-disciplinary open access archive for the deposit and dissemination of scientific research documents, whether they are published or not. The documents may come from teaching and research institutions in France or abroad, or from public or private research centers.
L'archive ouverte pluridisciplinaire HAL, est destinée au dépôt et à la diffusion de documents scientifiques de niveau recherche, publiés ou non, émanant des établissements d'enseignement et de recherche français ou étrangers, des laboratoires publics ou privés. 


\title{
Cetylpyridinium removal using phosphate-assisted electrocoagulation,
} electroreduction and adsorption on electrogenerated sorbents

\author{
Abdenacer Flilissa ${ }^{1}$, Philippe Méléard, André Darchen* \\ UMR CNRS nº226 Institut des Sciences Chimiques de Rennes, ENSCR, CS 50837, 35708 \\ Rennes Cedex 7, France \\ * Corresponding author: Tel.: +33 223238004. Fax: +33 223238199. \\ E-mail address: Andre.Darchen@ensc-rennes.fr (A. Darchen) \\ ${ }^{1}$ Present address: Laboratoire de Chimie Analytique, Département de Pharmacie, Faculté de \\ Médecine, Université Ferhat Abbas, Sétif 1, 19000 Algeria
}




\begin{abstract}
Cetylpyridinium $\left(\mathrm{CP}^{+}\right)$is a cationic surfactant that can be found in various effluents and known due its toxicity against aquatic organisms. The removal of this compound was investigated in water solutions by electrocoagulation, phosphate-assisted electrocoagulation and adsorption on electrogenerated adsorbents. Electrocoagulations were carried out with aluminum electrodes in $\mathrm{CP}^{+}$synthetic solutions. After $2 \mathrm{~h}$ of electrolysis in $0.1 \mathrm{M} \mathrm{NaCl}$ solutions, $\mathrm{CP}^{+}$was mainly removed by electroreduction at calculated rates of 0.024 and $0.0416 \mu \mathrm{mol} / \mathrm{C}$ corresponding to abatements of 28 and $24 \%$ for starting concentrations of $\mathrm{CP}^{+}$ at $0.5 \mathrm{mM}$ and $1.0 \mathrm{mM}$, respectively. The voltammetric study on steel or graphite electrodes confirmed a possible electroreduction of $\mathrm{CP}^{+}$which may explain its removal during electrolysis. The change of the cathode from aluminum to carbon or steel did not change notably the removal efficiency of electrolysis in $0.1 \mathrm{M} \mathrm{NaCl}$ solution. However, after $2 \mathrm{~h}$ of electrolysis in $0.1 \mathrm{M} \mathrm{NaCl}$ in the presence of $0.1 \mathrm{M}$ phosphate buffer, $\mathrm{CP}^{+}$was mainly removed by adsorption on electrogenerated aluminum phosphate with rates of 0.0694 and $0.138 \mu \mathrm{mol} / \mathrm{C}$ corresponding to abatements of $80 \%$ for 0.5 or $1 \mathrm{mM} \mathrm{CP}^{+}$solutions. The key role of phosphate ions was proved by adsorption experiments. The electro-synthesized alumina adsorbed $\mathrm{CP}^{+}$with a removal capacity of $10.2 \mathrm{mg} / \mathrm{g}$. But on electro-synthesized and chemical-synthesized aluminum phosphate the removal capacities were 94.2 and $165.3 \mathrm{mg} / \mathrm{g}$, respectively.
\end{abstract}

Key-words: Aluminum phosphate; Surfactants; Electrolysis; Alumina; Adsorption; Reduction 


\section{Introduction}

The increasing consumption of water and high-quality water drives the development of efficient water treatments and the research of new processes which are able to remove emerging pollutants [1]. Among these pollutants, surfactants constitute a large class of chemical substances that are widely used in domestic and industrial processes thanks to their physicochemical characteristics such as detergency, foaming, emulsification and dispersion effects. Surfactants are involved in various environmental pollutions with toxic effect on living organisms [2] and have raised problems in wastewater treatment plants [3]. Therefore, the removal of surfactants from wastewater is important in reducing their environmental impact. Classical techniques like oxidation, adsorption extraction or coagulation have been used. In this context electrochemical treatments and specially electrocoagulation (EC) have been applied in the removal of few surfactants $[4,5]$.

EC is a well-known electrochemical treatment which uses soluble anode materials in order to generate metal ions involved in a coagulation step [6,7]. According to Holt et al. [6] EC is a combination of physico-chemical processes including electrochemistry, coagulation and flotation. EC is efficient in the treatment of a large variety of effluents [8]. It is often emphasized that chemicals are not required in EC when it is directly applied to a wastewater. This is not strictly true because sacrificial anodes are consumed in all cases, and sometimes an efficient treatment needs a $\mathrm{pH}$ control and the addition of an electrolyte [9]. Generally, it is considered that the electrolyte is not consumed during $\mathrm{EC}$, but it can play a key role in the efficiency of the treatment [10] or in the structure of the electro-generated alumina [11]

Some pollutants are resistant to EC. This is the case with targeted compounds which are not involved in an electrochemical reaction or when they are not adsorbed on electrogenerated alumina. To overcome these difficulties, a new class of EC appears where chemicals are used as assistance in the process. Addition of ozone [12], hydrogen peroxide [13] or a chemical coagulant improves the corresponding assisted electrocoagulation.

In this paper we present a new example of a chemical-assisted EC applied to the removal of $\mathrm{N}$-cetylpyridium cation $\left(\mathrm{CP}^{+}\right)$from synthetic solutions. $\mathrm{CP}^{+}$is a cationic surfactant which exhibits toxicity against aquatic organisms [14]. The extensive use of $\mathrm{CP}^{+}$has led to the investigation of its removal from water solutions. Main methods use adsorption onto higharea activated carbon [15], or granular charcoal [16]. Photo-catalytic oxidation over $\mathrm{TiO}_{2}$ photo-catalyst [17] has also been investigated. In the present paper, the removal of $\mathrm{CP}^{+}$is 
investigated in classical EC and in a more efficient phosphate-enhanced EC. Reduction and adsorption on electrogenerated alumina, phosphate modified alumina and aluminum phosphate are removal ways of $\mathrm{CP}^{+}$.

\section{Materials and methods}

\subsection{Chemicals}

$\mathrm{CP}^{+}$solutions were prepared with $\mathrm{N}$-cetylpyridinium bromide $\left(\mathrm{C}_{21} \mathrm{H}_{38} \mathrm{NBr} 98 \%\right)$ from Aldrich. Sodium dihydrogen phosphate dihydrate $\left(\mathrm{NaH}_{2} \mathrm{PO}_{4} \cdot 2 \mathrm{H}_{2} \mathrm{O}\right.$ 99\%) and disodium hydrogen phosphate $\left(\mathrm{Na}_{2} \mathrm{HPO}_{4} 99 \%\right)$ were Prolabo analytical reagents. Sodium nitrate $\left(\mathrm{NaNO}_{3}, 99 \%\right)$, hydrochloric acid $(\mathrm{HCl} 36 \%)$, and sodium hydroxide $(\mathrm{NaOH} 99 \%)$ were Fluka reagents. Aluminum chloride hexahydrate $\left(\mathrm{AlCl}_{3} \cdot 6 \mathrm{H}_{2} \mathrm{O}\right.$, Prolabo $\left.99 \%\right)$ was used in the preparation of alumina and aluminum phosphate adsorbents. Phosphoric acid $\left(\mathrm{H}_{3} \mathrm{PO}_{4}, 85 \%\right)$, nitric acid $\left(\mathrm{HNO}_{3} 65 \%\right)$, sodium chloride $(\mathrm{NaCl} 99 \%)$, sulfuric acid $\left(\mathrm{H}_{2} \mathrm{SO}_{4} 96 \%\right)$, iron powder (97\%), zinc powder (97\%) and aluminum powder (99\%) were Fluka reagents. All aqueous solutions were prepared by dissolution in de-ionized water.

\subsection{Electrolysis}

$\mathrm{CP}^{+}$removal by EC was investigated in $0.1 \mathrm{M} \mathrm{NaCl}$ or in $0.1 \mathrm{M} \mathrm{NaCl}$ buffered by 0.1 $\mathrm{M} \mathrm{Na}_{2} \mathrm{HPO}_{4}$ and $0.1 \mathrm{M} \mathrm{NaH}_{2} \mathrm{PO}_{4}$. All the electrolyses were conducted at $0.2 \mathrm{~A}$ on $0.25 \mathrm{~L}$ of solution with aluminum electrodes with a surface of $15 \mathrm{~cm}^{2}$ (width $3 \mathrm{~cm}, 5 \mathrm{~cm}$ length). The gap between anode and cathode was $1.8 \mathrm{~cm}$. Solutions were magnetically stirred. Three or five cells were connected on series. One of these cells was used as a control. Before electrolysis the electrodes were immersed in $2 \mathrm{M} \mathrm{NaOH}$ solution for 2 min and then rinsed with de-ionized water, dried in an oven and finally weighed. The electrolysis current was supplied by a current generator (Microlab 300V-1A). During electrolysis, pH was measured with a $\mathrm{pH}$ meter (Metrohm 827) and a combined glass electrode. A turbidimeter (Hach 2100P) was used to measure turbidity. The conductivity was measured with a conductimeter (CDM MeterLab 210) and a conductivity cell (E61M013). In order to maintain a constant volume during the electrolyses the analyzed solutions were put back in the electrolytic cells. At the end of electrolysis, the electrolytic solution was filtered and the recovered solid was 
washed, oven dried at $105^{\circ} \mathrm{C}$, and finally weighed. Electrodes were weighed at the end of electrolysis. Steel and graphite cathodes which were used in electrolysis were of identical dimensions to those of the aluminum cathode.

\subsection{Voltammetric study}

The voltammetric behavior of $0.02 \mathrm{M} \mathrm{CP}^{+}$was investigated in $0.1 \mathrm{M} \mathrm{NaCl}$ solution at $22^{\circ} \mathrm{C}$. Solutions were deoxygenated by bubbling nitrogen for $15 \mathrm{~min}$. The working electrode was a micro-disk of glassy carbon of $4 \mathrm{~mm}$ diameter. The auxiliary electrode and the reference electrode were a rod of glassy carbon and a saturated calomel electrode (SCE), respectively. A potentiostat $\mathrm{EG}^{*} \mathrm{G}$ model 362 and a $\mathrm{XY}$ recorder were used in the recording of voltammograms.

\subsection{Aluminophosphate and phosphate-modified alumina}

Two kinds of aluminophosphate were prepared by electrolysis and chemical precipitation. In the discussion, they are designated by $\left(\mathrm{AlPO}_{4}\right)_{\mathrm{E}}$ and $\left(\mathrm{AlPO}_{4}\right)_{\mathrm{C}} \cdot\left(\mathrm{AlPO}_{4}\right)_{\mathrm{E}}$ was prepared by electrolysis at $0.2 \mathrm{~A}$ for $10 \mathrm{~h}$ with aluminum electrodes in $0.25 \mathrm{~L}$ of a buffer solution $0.1 \mathrm{M} \mathrm{Na}_{2} \mathrm{HPO}_{4}$ and $0.1 \mathrm{M} \mathrm{NaH}_{2} \mathrm{PO}_{4}$ in the presence of $0.1 \mathrm{M} \mathrm{NaCl}$. $\left(\mathrm{AlPO}_{4}\right)_{\mathrm{C}}$ was obtained by precipitation after addition of $\mathrm{Na}_{3} \mathrm{PO}_{4}$ solution to a solution of $\mathrm{AlCl}_{3}$. Phosphate modified alumina was prepared by adsorption of phosphate onto alumina. In a first time, alumina was prepared by electrolysis at $0.2 \mathrm{~A}$ for $10 \mathrm{~h}$ with aluminum electrodes in $0.25 \mathrm{~L}$ of $0.1 \mathrm{M} \mathrm{NaCl}$ solution. Then $0.2 \mathrm{~g}$ of the isolated alumina was stirred for $2 \mathrm{~h}$ in $50 \mathrm{~mL}$ of a 4 $\mathrm{mM} \mathrm{NaH} 2 \mathrm{PO}_{4}$ solution. The solid isolated was oven dried at $105^{\circ} \mathrm{C}$.

\subsection{Determination of $\mathrm{pH}$ at the point of zero charge ( $\mathrm{pHpzc}$ )}

The point of zero charge (PZC) of all solids was estimated by using the batch equilibrium technique [18]. In this purpose, $0.2 \mathrm{~g}$ of solid was treated with $50 \mathrm{~mL}$ of $0.1 \mathrm{M}$ $\mathrm{NaNO}_{3}$ solution which was used as an inert electrolyte. The initial $\mathrm{pH}(\mathrm{pHi})$ was adjusted in the range $3-11$ by addition of $0.01 \mathrm{M} \mathrm{NaOH}$ or $0.01 \mathrm{M} \mathrm{HNO}_{3}$. The suspensions were left for $24 \mathrm{~h}$ to reach their thermodynamic equilibrium on a rotary shaker operating at $350 \mathrm{rpm}$. After 
completion of the equilibrium time, the solutions were filtered and the final $\mathrm{pH}(\mathrm{pHf})$ of the filtrates was measured.

\subsection{Analysis}

UV-Vis spectrophotometer (Perkin Elmer Lambda 35) was used in quantitative analysis of $\mathrm{CP}^{+}$in solutions at $\lambda_{\max }=259 \mathrm{~nm}$ and an infrared spectrophotometer (FTIR Shimadzu) in analysis of the adsorbents. The specific area of adsorbents was determined by the BET method. The instrument used was a model AS1 KR/MP version 5.52 using a software version 2.01 and a stand-conditioning sample Micromeritics Flow Prep 060, set at a temperature between $140^{\circ} \mathrm{C}$ and $145^{\circ} \mathrm{C}$.

\subsection{Adsorption kinetic}

In each experiment, $50 \mathrm{~mL}$ of $\mathrm{CP}^{+}$solutions at $0.3 \mathrm{mM}, 0.5 \mathrm{mM}, 0.7 \mathrm{mM}$ or $0.9 \mathrm{mM}$ were stirred at $250 \mathrm{rpm}$ with $0.2 \mathrm{~g}$ of adsorbent at $22 \pm 1^{\circ} \mathrm{C}$. Samples were withdrawn at appropriate time intervals and centrifuged at $4000 \mathrm{rpm}$ for $10 \mathrm{~min}$. The $\mathrm{CP}^{+}$absorbance of the supernatant solution was measured. The initial $\mathrm{pH}$ value was maintained higher than the $\mathrm{pH}_{\mathrm{pzc}}$ by addition of few drops of a concentrated $\mathrm{NaOH}$ solution. The $\mathrm{CP}^{+}$uptake by adsorbents was calculated by Eq. (1) where $\mathrm{q}_{\mathrm{t}}\left(\mathrm{mmol} / \mathrm{g}\right.$ ) is the amount of adsorbed $\mathrm{CP}^{+}$at time $\mathrm{t}(\mathrm{min}), \mathrm{V}$ (L) is the volume of solution, $\mathrm{C}_{0}$ and $\mathrm{C}_{\mathrm{t}}(\mathrm{mmol} / \mathrm{L})$ are concentrations at initial and time $\mathrm{t}$, respectively and $\mathrm{m}(\mathrm{g})$ is the mass of adsorbent.

$\mathrm{q}_{\mathrm{t}}=\left(\mathrm{C}_{0}-\mathrm{C}_{\mathrm{t}}\right) \mathrm{V} / \mathrm{m}$

\subsection{Adsorption isotherm}

The isotherm studies were carried out using a range of initial $\mathrm{CP}^{+}$concentrations of 0.3 to $2.5 \mathrm{mM}$. A typical experiment was conducted in a batch process by adding $0.2 \mathrm{~g}$ of the adsorbent to $50 \mathrm{~mL}$ of $\mathrm{CP}^{+}$solution. The mixture was stirred at $250 \mathrm{rpm}$ for 3 and $6 \mathrm{~h}$ in the presence of adsorbents $\left(\mathrm{AlPO}_{4}\right)_{\mathrm{C}}$ and $\left(\mathrm{AlPO}_{4}\right)_{\mathrm{E}}$, respectively. The mixture was centrifuged at $4000 \mathrm{rpm}$ for $10 \mathrm{~min}$ and the residual $\mathrm{CP}^{+}$concentration was determined in the supernatant solution. The amount of adsorbed $\mathrm{CP}^{+}$at equilibrium $\mathrm{q}_{\mathrm{e}}(\mathrm{mmol} / \mathrm{g}$ ) was obtained by Eq. (2) where $\mathrm{C}_{0}$ and $\mathrm{C}_{\mathrm{e}}(\mathrm{mmol} / \mathrm{L})$ are initial concentration and equilibrium concentration of $\mathrm{CP}^{+}$, respectively, $\mathrm{V}(\mathrm{L})$ is the volume of solution, and $\mathrm{m}(\mathrm{g})$ is the mass of adsorbent. 
$\mathrm{q}_{\mathrm{e}}=\left(\mathrm{C}_{0}-\mathrm{C}_{\mathrm{e}}\right) \mathrm{V} / \mathrm{m}$

\section{Results and discussions}

\subsection{Electrocoagulation in $\mathrm{NaCl}$ solution}

The electrolysis of $\mathrm{CP}^{+}$was performed at $22^{\circ} \mathrm{C}$ in $0.1 \mathrm{M} \mathrm{NaCl}$ solution. The electrolysis current was controlled at $0.2 \mathrm{~A}$ in order to prevent an excessive foam formation. After 570 min of electrolysis, the mass loss of the anode was $0.77 \mathrm{~g}$ whereas the calculated value according to Faraday's law was $0.637 \mathrm{~g}$. The cathode showed also a mass loss of $0.28 \mathrm{~g}$ due to a cathodic corrosion. These mass losses of aluminum anode and cathode are classical observations during EC [19]. A mass of $2.6 \mathrm{~g}$ of the electrogenerated alumina was isolated at the end of the electrolysis.

Owing to the formation of alumina, the turbidity of the aqueous medium increased. Remarkably, as shown by results in Fig. 1, the turbidity increased with increasing $\mathrm{CP}^{+}$ concentration from 4 to $16 \mathrm{mM} \mathrm{CP}^{+}$. This observation shows that $\mathrm{CP}^{+}$is involved in the coagulation process. A correct explanation of that increased turbidity would require more experiments.

The $\mathrm{pH}$ increased at the beginning of electrolysis and reached an approximate constant value (Fig. 2). The greatest $\mathrm{pH}$ value shows a noteworthy decrease when the $\mathrm{CP}^{+}$ concentration increases. Without $\mathrm{CP}^{+}$the $\mathrm{pH}$ reaches 9 , whereas in solutions of $4 \mathrm{mM}, 8 \mathrm{mM}$ and $16 \mathrm{mM} \mathrm{CP}^{+}$the $\mathrm{pH}$ increases until 8.4, 8.0 and 7.5, respectively. An increase of the $\mathrm{pH}$ is frequently observed during $\mathrm{EC}$ in $\mathrm{NaCl}$ solution. It is explained by a partial formation of $\mathrm{Al}(\mathrm{OH})_{2} \mathrm{Cl}$ instead of the expected $\mathrm{Al}(\mathrm{OH})_{3}$ [11]. As explained below, the effect of $\mathrm{CP}^{+}$ concentration on the particular $\mathrm{pH}$ variation reveals the involvement of the reduction of $\mathrm{CP}^{+}$ during this EC.

In the absence of $\mathrm{CP}^{+}$in $\mathrm{NaCl}$ solution, the EC process can be described by Eqs. (3)(6). The anodic reaction (Eq. (3)) leads to the formation of $\mathrm{Al}^{3+}$ ions. The cathodic reduction of water (Eq. (4)) produces hydrogen and hydroxyl anion. $\mathrm{Al}^{3+}$ and $\mathrm{OH}^{-}$ions react to form alumina following Eq. (5). The structure of alumina depends upon the water content of $\mathrm{Al}_{2} \mathrm{O}_{3} \cdot \mathrm{xH}_{2} \mathrm{O}$. In most cases, $\mathrm{X}$-ray diffraction of the isolated electrogenerated alumina shows that $\mathrm{AlOOH}$ is the main compound obtained beside $\mathrm{Al}(\mathrm{OH})_{3}$ [11]. The overall reaction is summarized by Eq. (6). This only reaction does not account for the observed increase of $\mathrm{pH}$ 
which is explained by the concomitant reaction (Eq. (7)) where a chloride anion is involved in an anion exchange with the release of one hydroxyl anion [11].

$$
\begin{aligned}
& \mathrm{Al} \rightarrow \mathrm{Al}^{3+}+3 \mathrm{e}^{-} \\
& 3 \mathrm{H}_{2} \mathrm{O}+3 \mathrm{e}^{-} \rightarrow 3 / 2 \mathrm{H}_{2}+3 \mathrm{OH}^{-} \\
& 2 \mathrm{Al}^{3+}+6 \mathrm{OH}^{-} \rightarrow \mathrm{Al}_{2} \mathrm{O}_{3} \cdot \mathrm{xH}_{2} \mathrm{O}+(3-\mathrm{x}) \mathrm{H}_{2} \mathrm{O}(\mathrm{x}=0,1,2 \text { or } 3) \\
& 2 \mathrm{Al}+6 \mathrm{H}_{2} \mathrm{O} \rightarrow 3 \mathrm{H}_{2}+\mathrm{Al}_{2} \mathrm{O}_{3} \cdot \mathrm{xH}_{2} \mathrm{O}+(3-\mathrm{x}) \mathrm{H}_{2} \mathrm{O}(\mathrm{x}=0,1,2 \text { or } 3) \\
& \mathrm{Al}+3 \mathrm{H}_{2} \mathrm{O}+\mathrm{Cl}^{-} \rightarrow 3 / 2 \mathrm{H}_{2}+\mathrm{Al}(\mathrm{OH})_{2} \mathrm{Cl}+\mathrm{OH}^{-}
\end{aligned}
$$

In the presence of $\mathrm{CP}^{+}$, a coupling cathodic reduction happened following Eq. (8). The involvement of this reduction increased with the concentration of $\mathrm{CP}^{+}$. The consequence was a competition between two cathodic reactions (Eqs. (4) and (8)) and a decrease in the formation of hydroxyl anions and a lower $\mathrm{pH}$ increase as observed (Fig. 2).

$2 \mathrm{CP}^{+}+2 \mathrm{e}^{-} \rightarrow(\mathrm{CP})_{2}$

The $\mathrm{CP}^{+}$abatement observed after 570 min of electrolysis at $\mathrm{CP}^{+}$concentrations of 4 $\mathrm{mM}, 8 \mathrm{mM}$ and $16 \mathrm{mM}$ were $55 \%, 49 \%$ and $61 \%$, respectively. At $4 \mathrm{mM} \mathrm{CP}^{+}$the amount of $\mathrm{CP}^{+}$adsorbed on $2.6 \mathrm{~g}$ of electrogenerated alumina was $0.104 \mathrm{mmol}$ (see later in section 3.4.2). Assuming that the same amount of $\mathrm{CP}^{+}(0.104 \mathrm{mmol})$ was adsorbed during $\mathrm{EC}$, the abatement of $\mathrm{CP}^{+}$due to reduction during EC is calculated to be about $44.6 \%$ at initial $4 \mathrm{mM}$ $\mathrm{CP}^{+}$. The IR spectrum of the solid isolated after electrolysis of $4 \mathrm{mM} \mathrm{CP}^{+}$was in agreement with the presence of adsorbed surfactant and the dimer $(\mathrm{CP})_{2}$. The bands which were observed at 2930 and $2863 \mathrm{~cm}^{-1}$ were attributed to the stretching of $\mathrm{CH}_{2}$ in the cetyl group [20]. These stretching vibrations do not allow a distinction between $\mathrm{CP}^{+}$and its reduction product.

\section{Fig. 1.}

Fig. 2.

In order to minimize the reduction of $\mathrm{CP}^{+}$, electrolyses were realized with initial $\mathrm{CP}^{+}$ concentrations of $0.5 \mathrm{mM}$ and $1 \mathrm{mM}$ (amount of $0.125 \mathrm{mmol}$ and $0.25 \mathrm{mmol}$ of $\mathrm{CP}^{+}$in 0.25 L). The variations of $\mathrm{CP}^{+}$concentration versus electrolysis time are represented in Fig. 3 . After 810 min of electrolysis, an almost complete removal of $\mathrm{CP}^{+}$was observed and $3.2 \mathrm{~g}$ of alumina were isolated. The alumina amount allowed a $95 \% \mathrm{CP}^{+}$removal involving 
adsorption. At initial $\mathrm{CP}^{+}$concentration of $1 \mathrm{mM}$, the observed yield of $\mathrm{CP}^{+}$removal was 2.44 $10^{-5} \mathrm{mmol} / \mathrm{C}$ or $0.078 \mathrm{mmol} / \mathrm{g}$ of electrogenerated alumina, or $2.35 \mathrm{mmol}$ of $\mathrm{CP}^{+} / \mathrm{mol}$ of electrons.

Fig. 3.

\subsection{Reduction of $C P^{+}$}

This investigation was carried out in order to prove the reduction of $\mathrm{CP}^{+}$during $\mathrm{EC}$ experiments and to find if this reaction would be an efficient electrochemical treatment. The possibility of a reduction during EC is not surprising since the involvement of reduction is well known during the removal of nitrate anions [21] and pyridinium cations are known as reducible substrates on various electrode materials [22].

\subsubsection{Voltammetry of $\mathrm{CP}^{+}$}

The voltammetric study was performed in $0.1 \mathrm{M} \mathrm{NaCl}$ solution at a working electrode of glassy carbon. The voltammograms show a one-electron irreversible cathodic peak at $1.05 \mathrm{~V} / \mathrm{SCE}$ and one irreversible anodic peak at $-0.02 \mathrm{~V} / \mathrm{SCE}$ (Fig. 4). Both peaks increase with the $\mathrm{CP}^{+}$concentration. The cathodic peak current is proportional to the $\mathrm{CP}^{+}$ concentration. The one-electron reduction leads to a neutral radical which undergoes a fast dimerization. The anodic peak is rather symmetric in agreement with the oxidation of adsorbed species. The anodic peak was observed only after the cathodic one proving that the oxidation must be attributed to the oxidation of the reduced compound which was formed during the cathodic potential scan. The voltammetric behavior of $\mathrm{CP}^{+}$is summarized in Fig. 5, assuming that the dimer is the $4,4^{\prime}$ ' coupled isomer. During the anodic potential scan, the dimer is oxidized leading to the starting substrate. Owing to this chemical reversibility, repetitive potential scans did not show a current decrease. The potential of the electrochemical reduction was constant in the $\mathrm{pH}$ range 1-13, as expected when a process does not involve protonation. This electrochemical behavior is analogous to the one of $\mathrm{N}$-alkylpyridinium cations [22].

Fig. 4.

Fig. 5. 


\subsubsection{Effect of the cathode during EC}

In order to check the behavior of $\mathrm{CP}^{+}$and its abatement during EC different cathodes were used. Electrolyses were carried out in $0.1 \mathrm{M} \mathrm{NaCl}$ solution with aluminum anode and steel or graphite cathodes. Electrolyses were carried out for 0.5 and $1 \mathrm{mM} \mathrm{CP}^{+}$under a current of 0.2 A. Fig. 6 shows the decrease of the $\mathrm{CP}^{+}$concentration as a function of electrolysis time. The abatements of $\mathrm{CP}^{+}$seem similar to what is observed with an aluminum cathode. After 570 min of electrolysis, abatements reached $59 \%$ and $68 \%$ at $\mathrm{CP}^{+}$initial concentrations of 1 $\mathrm{mM}$, when cathodes were steel and graphite, respectively. An abatement of $67 \%$ was observed after 570 min of electrolysis when an aluminum cathode was used (Fig. 3).

\section{Fig. 6 .}

\subsubsection{Reduction of $\mathrm{CP}^{+}$by metal powder}

The chemical reduction of $\mathrm{CP}^{+}$was investigated in order to confirm its possible removal by reduction. Aluminum, zinc and iron were used at $\mathrm{pH} 13.3,1.2$ and 1.5, respectively, in order to prevent the passivity of these reducing metals. The apparent standard potentials of $\mathrm{Al}$ and $\mathrm{Zn}$ at $\mathrm{pH} 13.3$ and 1.2 are $-2.31 \mathrm{~V} / \mathrm{SHE}$ and $-0.76 \mathrm{~V} / \mathrm{SHE}$, respectively. These metals are able to reduce $\mathrm{CP}^{+}$which shows a cathodic peak at $-0.80 \mathrm{~V} / \mathrm{SHE}$, taking the potential of the SCE at $+0.246 \mathrm{~V} / \mathrm{SHE}$. The treatment of $1 \mathrm{mM} \mathrm{CP}^{+}$solutions by stoichiometric quantities of $\mathrm{Al}$ and $\mathrm{Zn}$ powder afforded a $90 \%$ abatement of $\mathrm{CP}^{+}$. As expected by the low standard potential of iron at $-0.44 \mathrm{~V} / \mathrm{SHE}$, iron powder did not reduce $\mathrm{CP}^{+}$.

\subsection{EC in the presence of phosphate ions}

EC was carried out in the presence of phosphate ions in order to modify the structure of the electrogenerated adsorbent. It is well known that EC is efficient in the removal of phosphate [23] and this is in agreement with the formation of insoluble aluminophosphate. EC was performed at $0.2 \mathrm{~A}$ for $420 \mathrm{~min}$ in $0.1 \mathrm{M} \mathrm{NaCl}$ solution buffered by $0.1 \mathrm{M} \mathrm{Na}_{2} \mathrm{HPO}_{4}$ and $0.1 \mathrm{M} \mathrm{NaH}_{2} \mathrm{PO}_{4}$. At the end of the electrolysis, the experimental mass losses of aluminum anodes and cathodes were $0.550 \mathrm{~g}$ and $0.12 \mathrm{~g}$, respectively. The mass loss due to corrosion of both electrodes is calculated at $0.2 \mathrm{~g}$.

Fig. 7 shows the variation of $\mathrm{pH}$ during electrolysis in the presence or without $\mathrm{CP}^{+}$. For the first $3 \mathrm{~h}$, the $\mathrm{pH}$ increased slowly from 6.4 to 7.0, in agreement with a buffer effect of phosphate compounds. Then, for the $4^{\text {th }}$ hour, the $\mathrm{pH}$ increase was faster and reached 9.6. 
These $\mathrm{pH}$ variations contrast with the results of Fig. 2 and look like the titration curve of an acid by a base showing a pseudo equivalent point at about $250 \mathrm{~min}$. Analogous $\mathrm{pH}$ variation has been already observed during $\mathrm{EC}$ of $\mathrm{H}_{3} \mathrm{PO}_{4}$ solutions [24]. In this case, the equivalence point corresponds to the total transformation of phosphoric acid into aluminum phosphate. In the case of Fig. 7, the interpretation is slightly different. Considering the formation of $\mathrm{AlPO}_{4}$ by reaction of $\mathrm{Al}^{3+}$ following Eq. (9). The combination of Eqs. (3), (4), (9) and (10) gives the overall reaction (Eq. (11)) which shows that one mole of $\mathrm{Al}^{3+}$ arising from anode dissolution consumes 2 moles of $\mathrm{H}_{2} \mathrm{PO}_{4}^{-}$. Considering the formation of alumina by aluminum corrosion (Eq. (12)) where alumina is written $\mathrm{Al}(\mathrm{OH})_{3}$ in order to simplify. The involvement of Eqs. (10) and (12) in the formation of $\mathrm{AlPO}_{4}$ (Eq. (13)) gives the overall Eq. (14) which is identical to Eq. (11). This relation also shows that one mole of $\mathrm{Al}(\mathrm{OH})_{3}$ arising from $\mathrm{Al}$ corrosion consumes 2 moles of $\mathrm{H}_{2} \mathrm{PO}_{4}{ }^{-}$and gives one mole of the basic specie $\mathrm{HPO}_{4}{ }^{2-}$ which is involved in the $\mathrm{pH}$ increase.

$$
\begin{aligned}
& \mathrm{Al}^{3+}+\mathrm{H}_{2} \mathrm{PO}_{4}^{-} \rightarrow \mathrm{AlPO}_{4}+2 \mathrm{H}^{+} \\
& \mathrm{H}_{2} \mathrm{PO}_{4}^{-}+\mathrm{OH}^{-} \rightarrow \mathrm{HPO}_{4}{ }^{2-}+\mathrm{H}_{2} \mathrm{O} \\
& \mathrm{Al}+2 \mathrm{H}_{2} \mathrm{PO}_{4}^{-} \rightarrow \mathrm{AlPO}_{4}+3 / 2 \mathrm{H}_{2}+\mathrm{HPO}_{4}{ }^{2-} \\
& \mathrm{Al}+3 \mathrm{H}_{2} \mathrm{O} \rightarrow \mathrm{Al}(\mathrm{OH})_{3}+3 / 2 \mathrm{H}_{2} \\
& \mathrm{Al}(\mathrm{OH})_{3}+\mathrm{H}_{2} \mathrm{PO}_{4}^{-} \rightarrow \mathrm{AlPO}_{4}+2 \mathrm{H}_{2} \mathrm{O}+\mathrm{OH}^{-} \\
& \mathrm{Al}+2 \mathrm{H}_{2} \mathrm{PO}_{4}^{-} \rightarrow \mathrm{AlPO}_{4}+3 / 2 \mathrm{H}_{2}+\mathrm{HPO}_{4}{ }^{2-}
\end{aligned}
$$

Fig. 7.

From the mass loss of electrodes at the end of electrolysis, the amount of Al which was corroded at the pseudo-equivalence of $250 \mathrm{~min}$ was calculated at $0.119 \mathrm{~g}$ corresponding to the possible formation of $4.41 \mathrm{mmol}$ of $\mathrm{Al}(\mathrm{OH})_{3}$. At the same time, the quantity of $\mathrm{Al}^{3+}$ was 10.36 mmol according to Faraday's law. $\mathrm{Al}^{3+}$ and $\mathrm{Al}(\mathrm{OH})_{3}$ allow the disappearance of $29.54 \mathrm{mmol}$ of $\mathrm{H}_{2} \mathrm{PO}_{4}{ }^{-}$and $250 \mathrm{~mL}$ of the $0.1 \mathrm{M} \mathrm{H}_{2} \mathrm{PO}_{4}{ }^{-}$solution contained $25 \mathrm{mmol}$ of $\mathrm{H}_{2} \mathrm{PO}_{4}{ }^{-}$. So, the pseudo-equivalence observed at $250 \mathrm{~min}$ is not in a very good agreement with the formation of an aluminophosphate written as $\mathrm{AlPO}_{4}$ in this paper. The difference between the calculated and the observed values may be attributed to a difference between the real structure of the aluminophosphate and $\mathrm{AlPO}_{4}$.

The variation of $\mathrm{CP}^{+}$concentration during $\mathrm{EC}$ in the presence of a phosphate buffer is given in Fig. 8. At the end of electrolyses, a mass of $3.37 \mathrm{~g}$ of dried aluminophosphate was 
isolated. The $\mathrm{CP}^{+}$abatement shown in Fig. 8 is at $95 \%$ after $3 \mathrm{~h}$ of electrolysis. The abatement can be calculated at this time at initial $\mathrm{CP}^{+}$concentration of $1 \mathrm{mM}$. It was $0.164 \mathrm{mmol} / \mathrm{g}$ of electrogenerated $\mathrm{AlPO}_{4}$ or $10.9710^{-5} \mathrm{mmol} / \mathrm{C}$ or $10.59 \mathrm{mmol} / \mathrm{mol}$ of electrons. In the presence of a phosphate buffer, the $\mathrm{CP}^{+}$removal during $\mathrm{EC}$ was 4.5 times more efficient than in the absence of this buffer.

Fig. 8 .

\subsection{Adsorption}

\subsubsection{Structure of the investigated adsorbents}

The structure of the alumina electrogenerated in $\mathrm{NaCl}$ solutions is already described as a mixture of boehmite $\mathrm{AlOOH}$ and bayerite $\mathrm{Al}(\mathrm{OH})_{3}$ [5,11]. The $\mathrm{XRD}$ of $\left(\mathrm{AlPO}_{4}\right)_{\mathrm{C}}$ and $\left(\mathrm{AlPO}_{4}\right)_{\mathrm{E}}$ showed an amorphous structure. The phosphate-modified alumina was prepared by immersion of an electrogenerated alumina into a $4 \mathrm{mM} \mathrm{NaH}_{2} \mathrm{PO}_{4}$ solution. During this immersion the alumina surface was modified thanks to an efficient phosphate adsorption [23]. The analysis of P by EDS gave a weight content of $1.54 \%$. The specific surface area of solids were determined by BET method and gave 100 and $27 \mathrm{~m}^{2} / \mathrm{g}$ for $\left(\mathrm{AlPO}_{4}\right)_{\mathrm{C}}$ and $\left(\mathrm{AlPO}_{4}\right)_{\mathrm{E}}$, respectively, and $217 \mathrm{~m}^{2} / \mathrm{g}$ for alumina arising from $\mathrm{EC}$ in $0.1 \mathrm{M} \mathrm{NaCl}$. The large difference between BET surface areas of $\left(\mathrm{AlPO}_{4}\right)_{\mathrm{C}}$ and $\left(\mathrm{AlPO}_{4}\right)_{\mathrm{E}}$ probably arises from the kinetics of the synthesis ways. The chemical synthesis is faster than the electrochemical one and this allows the formation of a higher surface. The $\mathrm{pH}_{\mathrm{pzc}}$ of $\left(\mathrm{AlPO}_{4}\right)_{\mathrm{C}}$ and $\left(\mathrm{AlPO}_{4}\right)_{\mathrm{E}}$ were respectively 4.75, 7.55 and the $\mathrm{pH}_{\mathrm{pzc}}$ of the electrogenerated alumina was 8.1.

\subsubsection{Adsorption of $\mathrm{CP}^{+}$on electrogenerated adsorbents}

In order to verify the removal of $\mathrm{CP}^{+}$by adsorption, electrolyses were carried out in $0.1 \mathrm{M} \mathrm{NaCl}$ and in the absence of $\mathrm{CP}^{+}$for $570 \mathrm{~min}$. The experimental mass loss of both electrodes was $1.0 \mathrm{~g}$ including the mass loss of cathode by corrosion. At the end of electrolyses, $\mathrm{CP}^{+}$was added at the concentrations of 2 and $4 \mathrm{mM}$ and its concentration was measured. After $2 \mathrm{~h}$ of stirring, at initial concentration of $4 \mathrm{mM}$, the results showed that the rate of $\mathrm{CP}^{+}$removal was calculated to be $0.04 \mathrm{mmol} / \mathrm{g}$. This $\mathrm{CP}^{+}$adsorption on $2.6 \mathrm{~g}$ of electrogenerated alumina corresponds to $1.47 \mathrm{mmol} / \mathrm{mol}$ of electrons. This result shows that $\mathrm{EC}$ was more efficient than adsorption in the removing of $\mathrm{CP}^{+}$. 
Electrolyses were carried out in $0.1 \mathrm{M} \mathrm{NaCl}$ buffered with phosphate buffer without surfactant. After $420 \mathrm{~min}$ of electrolysis, $3.2 \mathrm{~g}$ of an oven dried solid of aluminophosphate were isolated. They were added to a cell that contained $0.25 \mathrm{~L}$ of $1 \mathrm{mM} \mathrm{CP}^{+}$. The mixture was magnetically stirred and the change in concentration of $\mathrm{CP}^{+}$was observed. The results showed a $97 \%$ decrease of $\mathrm{CP}^{+}$after $2 \mathrm{~h}$ corresponding to $0.076 \mathrm{mmol} / \mathrm{g}$ of $\mathrm{AlPO}_{4}$ or $4.8210^{-5}$ $\mathrm{mmol} / \mathrm{C}$ or $4.65 \mathrm{mmol} / \mathrm{mol}$ of electrons. In this experiment, the adsorption on electrogenerated $\mathrm{AlPO}_{4}$ is 3.16 times more efficient than adsorption on electrogenerated alumina. The result also shows that EC in the presence of a phosphate buffer was more efficient than adsorption on electrogenerated $\mathrm{AlPO}_{4}$ in removing $\mathrm{CP}^{+}$.

The IR spectra of the isolated solids were in agreement with the presence of adsorbed $\mathrm{CP}^{+}$as shown by the vibration bands at 2925 and $2853 \mathrm{~cm}^{-1}$ which were attributed to the stretching of $-\mathrm{CH}_{2}-$ of the cetyl group.

\subsubsection{Adsorption kinetics of $\mathrm{CP}^{+}$on aluminophosphate}

Various models are available to study the kinetics of adsorption. Two models were used in the adsorption of $\mathrm{CP}^{+}$onto $\left(\mathrm{AlPO}_{4}\right)_{\mathrm{E}}$ and $\left(\mathrm{AlPO}_{4}\right)_{\mathrm{C}}$ : the pseudo-first-order and the pseudo-second-order. The Lagergren rate equation is one of the most widely used rate relation to describe the adsorption process. The pseudo-first-order equation is given by Eq. (15) [25], whereas the pseudo-second-order model is rather governed by Eq. (16) as described in the literature [26] where $\mathrm{q}_{\mathrm{e}}(\mathrm{mmol} / \mathrm{g})$ and $\mathrm{q}_{\mathrm{t}}(\mathrm{mmol} / \mathrm{g})$ are the amounts of $\mathrm{CP}^{+}$adsorbed at equilibrium and at time $\mathrm{t}$, respectively, $\mathrm{k}_{1}\left(\mathrm{~min}^{-1}\right)$ and $\mathrm{k}_{2}(\mathrm{~g} / \mathrm{mmol} \mathrm{min})$ are rate constants of the first order and the second order, respectively.

$\log \left(\mathrm{q}_{\mathrm{e}}-\mathrm{q}_{\mathrm{t}}\right)=\log \mathrm{q}_{\mathrm{e}}-\mathrm{k}_{1} \mathrm{t} / 2.303$

$\mathrm{t} / \mathrm{q}_{\mathrm{t}}=1 / \mathrm{k}_{2} \mathrm{q}_{\mathrm{e}}^{2}+\mathrm{t} / \mathrm{q}_{\mathrm{e}}$

The experimental study of the adsorption kinetics of $\mathrm{CP}^{+}$on $\left(\mathrm{AlPO}_{4}\right)_{\mathrm{C}}($ Fig. 9a1) showed a fast adsorption in the first minutes and reached a steady state, particularly at concentrations below the Critical Micelle Concentration (CMC). The $\mathrm{CMC}$ of $\mathrm{CP}^{+}$bromide in water at $25^{\circ} \mathrm{C}$ is of $0.7 \mathrm{mmol} / \mathrm{L}$ [27]. The $\mathrm{CMC}$ of $\mathrm{CP}^{+}$bromide in $0.1 \mathrm{M} \mathrm{NaCl}$ solution was determined by UV-Vis and was found to be $0.016 \mathrm{mmol} / \mathrm{L}$.

The linear relations (Eqs. (15) and (16)) were used in the investigation of the adsorption process. For the first order, $\log \left(\mathrm{q}_{\mathrm{e}}-\mathrm{q}_{\mathrm{t}}\right)$ was plotted versus $\mathrm{t}$. The values of $\mathrm{k}_{1}$ were 
calculated from the slope of the linear plots. For the second order, $\mathrm{t} / \mathrm{q}_{\mathrm{t}}$ was plotted versus $\mathrm{t}$. The values of $\mathrm{q}_{\mathrm{e}}$ were obtained from 1/slope, and from intercept $\left(1 / \mathrm{k}_{2} \mathrm{q}_{\mathrm{e}}{ }^{2}\right) \mathrm{k}_{2}$ can be calculated. The correlations coefficient values $\mathrm{R}^{2}$ showed that the pseudo-second-order model gave a better fit than the pseudo-first-order model. The coefficients $\mathrm{R}^{2}$ are in the ranges 0.9994 0.9804 and $1-0.9999$ for $\left(\mathrm{AlPO}_{4}\right)_{\mathrm{E}}$, and $\left(\mathrm{AlPO}_{4}\right)_{\mathrm{C}}$ respectively (Table 1). These values are significantly higher than those obtained with a pseudo-first-order model. Results for the second order are gathered in Table 1: The rate constant decreases from 0.9205 to 0.0693 $\mathrm{g} / \mathrm{mmol} \mathrm{min}$ and 16.63 to $1.555 \mathrm{~g} / \mathrm{mmol} \mathrm{min}$, for $\left(\mathrm{AlPO}_{4}\right)_{\mathrm{E}}$, and $\left(\mathrm{AlPO}_{4}\right)_{\mathrm{C}}$, respectively when the initial surfactant concentration increases from $0.3 \mathrm{mM}$ to $0.9 \mathrm{mM}$. $\mathrm{q}_{\mathrm{e}}$ increases with the initial concentration of $\mathrm{CP}^{+}$. Experimental values of $\mathrm{q}_{\mathrm{e}}$ are very close to calculated values (Table1).

The kinetics of adsorption of $\mathrm{CP}^{+}$on $\left(\mathrm{AlPO}_{4}\right)_{\mathrm{E}}(\mathrm{Fig} .9 \mathrm{~b} 1)$ was slower than on $\left(\mathrm{AlPO}_{4}\right)_{\mathrm{C}}$ and its adsorption capacity at equilibrium was lower than the one found for $\left(\mathrm{AlPO}_{4}\right)_{\mathrm{C}}$.

\section{Table 1.}

\subsubsection{Adsorption isotherms of $\mathrm{CP}^{+}$on aluminophosphate}

For a solid-liquid system, the equilibrium of adsorption is one of the important physico-chemical aspects in the description of adsorption behavior.

The adsorption isotherm of $\mathrm{CP}^{+}$on $\left(\mathrm{AlPO}_{4}\right)_{\mathrm{C}}$ shows a maximum adsorption capacity of $0.43 \mathrm{mmol} / \mathrm{g}\left(165.3 \mathrm{mg} / \mathrm{g}\right.$ ) (Fig. 9a2). The initial $\mathrm{CP}^{+}$concentrations were chosen higher than its $\mathrm{CMC}(\mathrm{Ce}>\mathrm{CMC})$. At these concentrations the adsorption onto $\left(\mathrm{AlPO}_{4}\right)_{\mathrm{C}}$ increases and the $\mathrm{CP}^{+}$is associated with the adsorbent by lateral interactions between the hydrocarbon chains. $\mathrm{CP}^{+}$was assumed to be adsorbed as hemimicelles and by the formation of admicelles between 0.02 and $0.2 \mathrm{mM}$ [28] and hemimicelles - admicelles between 0.2 and $0.3 \mathrm{mM}$ [29]. The isotherm at concentrations $\mathrm{Ce}>\mathrm{CMC}$ is of type III. It corresponds to a solid non-porous or porous which is characterized by weak interactions adsorbate/adsorbent.

The rate of adsorption of $\mathrm{CP}^{+}$on $\left(\mathrm{AlPO}_{4}\right)_{\mathrm{E}}$ is slower than that obtained on $\left(\mathrm{AlPO}_{4}\right)_{\mathrm{C}}$ especially at concentrations above the CMC (Fig. 9b2). The isotherm shows the greatest adsorption capacity at $0.245 \mathrm{mmol} / \mathrm{g}(94.19 \mathrm{mg} / \mathrm{g})$. The results between 0.08 and $0.25 \mathrm{mM}$ show a fast formation of admicelle [30] and the formation of hemimicelles - admicelle [29]. The isotherm at concentrations $\mathrm{Ce}>\mathrm{CMC}$ is of type III.

Fig. 9. 


\subsubsection{Adsorption kinetics and isotherm of $\mathrm{CP}^{+}$on phosphate-modified alumina}

The variation in the adsorption capacity of $\mathrm{CP}^{+}$as a function of $\mathrm{pH}$ on an alumina modified by adsorbed phosphate showed a maximum adsorption capacity of $0.06 \mathrm{mmol} / \mathrm{g}$ at pH 6.9. The adsorption study was performed with $0.3 \mathrm{mM}$ and $1 \mathrm{mM} \mathrm{CP}^{+}$concentrations. The adsorption rate was slower than to the one obtained on $(\mathrm{AlPO} 4)_{\mathrm{C}}$ but equivalent to the rate of adsorption on (AlPO4) $)_{\mathrm{E}}$. The results are shown in Fig. 10a.

The application of pseudo-first-order and pseudo-second-order models in the adsorption kinetics gives a better fit with the pseudo-second-order model with $\mathrm{R}^{2}$ values greater than 0.99. XRD diagrams of the modified and unmodified alumina showed a slight difference which may be attributed to the presence of adsorbed phosphate on the surface of the alumina. The adsorption isotherm of the modified alumina $\mathrm{CP}^{+}$has an adsorption capacity of $0.275 \mathrm{mmol} / \mathrm{g}$ (Fig. 10b).

Fig. 10.

\subsubsection{Comparison of the investigated adsorbents}

Three kinds of adsorbents were investigated in this work: two electrogenerated adsorbents: alumina and $\left(\mathrm{AlPO}_{4}\right)_{\mathrm{E}}$, one alumina modified by adsorbed phosphate and one chemically synthesized phosphate $\left(\mathrm{AlPO}_{4}\right)_{\mathrm{C}}$. The results of adsorption capacity showed that $\mathrm{EC}$ was more efficient in $\mathrm{CP}^{+}$removal than adsorption on the corresponding electrogenerated adsorbents. The alumina modified by adsorbed phosphate and all AlPO4 were more efficient in $\mathrm{CP}^{+}$removal than alumina. The best adsorption capacity was observed on the aluminum phosphate chemically synthesized $\left(\mathrm{AlPO}_{4}\right)_{\mathrm{C}}$.

\section{Conclusion}

For the first time, the removal of $\mathrm{CP}^{+}$was investigated by $\mathrm{EC}$ using aluminum electrodes. The study revealed that this EC was a complicated process involving electroreduction of $\mathrm{CP}^{+}$and adsorption on electrogenerated adsorbents. The efficiency of the $\mathrm{CP}^{+}$removal was improved by performing $\mathrm{EC}$ in the presence of phosphate ions. The $\mathrm{pH}$ variations during EC were informative about two reactions which are involved: (i) the reduction of $\mathrm{CP}+$ in competition with water reduction and (ii) the formation of aluminophosphate when EC was performed in the presence of phosphate ions. The efficiency 
of the $\mathrm{CP}+$ removal during EC was confirmed by an adsorption study. Results showed the following order of decreasing adsorption capacity: $\left(\mathrm{AlPO}_{4}\right)_{\mathrm{C}}>$ alumina modified by adsorbed phosphate $>\left(\mathrm{AlPO}_{4}\right)_{\mathrm{E}}>$ electrogenerated alumina. The $\mathrm{CP}^{+}$removal was more efficient during the EC treatments than by adsorption on the corresponding electrogenerated adsorbents alumina or aluminophosphate.

\section{Acknowledgements}

The authors thank CNRS (UMR 6226) and the French Ministry of National Education for positions and support. One of us (A. Flilissa) wishes to express his gratitude to the Ministère de l'Enseignement Supérieur et de la Recherche Scientifique of Algeria for a doctoral fellowship.

\section{References}

[1] M. La Farre, S. Perez, L. Kantiani, D. Barcelo, Fate and toxicity of emerging pollutants, their metabolites and transformation products in aquatic environment, Trends Anal. Chem. 27 (2008) 991-1007.

[2] T. Ivankovic, J. Hrenovic, Surfactants in the environment, Arch. Ind. Hyg. Toxicol. 61 (2010) 95-110.

[3] J. Hrenovic, T. Ivankovic, Toxicity of anionic and cationic surfactant to Acinetobacter junii in pure culture, Cent. Eur. J. Biol. 2 (2007) 405-414.

[4] E. Onder, A.S. Koparal, U.B. Ogutveren, An alternative method for the removal of surfactants from water: electrochemical coagulation, Sep. Purif. Technol. 52 (2007) 527532.

[5] A. Flilissa, A. Darchen, P. Méléard, Selective removal of dodecyl sulfate during electrolysis with aluminum electrodes, Desalination Water Treat. 51 (2013) 6719-6728.

[6] P.K. Holt, G.W. Barton, C.A. Mitchell, The future for electrocoagulation as a localized water treatment technology, Chemosphere, 59 (2005) 355-367.

[7] H. Liu, X. Zhao, J. Qu, Electrocoagulation in water treatment in C. Comninellis, G. Chen (Eds), Electrochemistry for the Environment (2010) 245-262. 
[8] I. Kabdasli, I. Arslan-Alaton, T. Olmez-Hanci, O. Tunay, Electrocoagulation applications for industrial wastewaters: a critical review, Environ. Technol. Rev. 1 (2012) 2-45.

[9] M. Mechelhoff, G.H. Kelsall, N.J.D. Graham, Electrochemical behavior of aluminium in electrocoagulation processes, Chem. Eng. Sci. 95 (2013) 301-312.

[10] J.L. Trompette, H. Vergnes, On the crucial influence of some supporting electrolytes during electrocoagulation in the presence of aluminum electrodes, J. Hazard. Mater. 163 (2009) 1282-1288.

[11] E. Tchomgui-Kamga, N. Audebrand, A. Darchen, Effect of co-existing ions during the preparation of alumina by electrolysis with soluble aluminum electrodes: structure and defluoridation activity of electro-synthesized adsorbents, J. Hazard. Mater. 254-255 (2013) $125-133$.

[12] S. Song, Z. He, J. Qiu, L. Xu, J. Chen, Ozone assisted electrocoagulation for decolorization of C.I. Reactive Black 5 in aqueous solution: an investigation of the effect of operational parameters, Sep. Purif. Technol. 55 (2007) 238-245.

[13] G. Roa-Morales, E. Campos-Medina, J. Aguilera-Cotero, B. Bilyeu, C. Barrera-Diaz, Aluminum electrocoagulation with peroxide applied to wastewater from pasta and cookie processing, Sep. Purif. Technol. 54 (2007) 124-129.

[14] J. Hrenovic, T. Ivankovic, L. Sekovanic, M. Rozic, Toxicity of dodecylpyridinium and cetylpyridinium chlorides against phosphate-accumulating bacterium, Cent. Eur. J. Biol. 3 (2008) 143-148.

[15] O. Duman, E. Ayranci, Adsorptive removal of cationic surfactants from aqueous solutions onto high-area activated carbon cloth monitored by in situ UV spectroscopy, J. Hazard. Mater. 174 (2010) 359-367.

[16] M.M. Saleh, On the removal of cationic surfactants from dilute streams by granular charcoal, Water Res. 40 (2006) 1052-1060.

[17] B. Singhal, A. Porwal, A. Sharma, R. Ameta, S.C. Ameta, Photocatalytic degradation of cetyl pyridinium chloride over titanium dioxide powder, J. Photochem. Photobiol A: Chem. 108 (1997) 85-88.

[18] F. Gaboriaud, J.J. Ehrhardt, Effect of different crystal faces on the surface charge of colloidal goethite $(\alpha-\mathrm{FeOOH})$ particles: an experimental and modeling study, Geochimica Cosmochimica Acta 67 (2003) 967-983.

[19] M. Mechelhoff, G.H. Kelsall, N.J.D. Graham, Super-faradaic charge yields for aluminium dissolution in neutral aqueous solutions, Chem. Eng. Sci. 95 (2013) 353-359. 
[20] K.-H.S. Kung, K.F. Hayes, Fourier transform infrared spectroscopic study of the adsorption of cetyltrimethylammonium bromide and cetylpyridinium chloride on silica, Langmuir, 9 (1993) 263-267.

[21] A.S. Koparal, U.B. Ogutveren, Removal of nitrate from water by electroreduction and electrocoagulation, J. Hazard. Mater. 89 (2002) 83-94.

[22] J.G. Gaudiello, D. Larkin, J.D. Rawn, J.J. Sosnowski, E.E. Bancroft, H.N. Blount, On the mechanism of the electrochemical reduction of N-methylpyridinium ion, J. Electroanal. Chem. 131 (1982) 203-214.

[23] S. Tanada, M. Kabayama, N. Kawasaki, T. Sakiyama, T. Nakamura, M. Araki, T. Tamura, Removal of phosphate by aluminium oxide hydroxide, J. Colloid Interface Sci. 257 (2003) 135-140.

[24] S. Tchamango, C.P. Nanseu-Njiki, E. Ngameni, D. Hadjiev, A. Darchen, Treatment of dairy effluents by electrocoagulation using aluminum electrodes, Sci. Total Environ. 408 (2010) 947-952.

[25] S. Lagergren, Zur theorie der sogenannten adsorption geloster stoffe, Kungliga Svenska Vetenskapsakademiens. Handligar 24 (1898) 1-39.

[26] Y.S. Ho, Second-order-kinetic model for the sorption of cadmium onto tree fern: a comparison of linear and non-linear methods, Water Res. 40 (2006) 119-125.

[27] J.J. Chung, S.W. Lee, J.H. Choi, Salt effects on the critical micelle concentration and counterion binding of cetylpyridinium bromide micelles, Bull Korean chem. Soc. 12 (1991) 411-413.

[28] M. Ghiaci, R. Kia, R.J. Kalbasi, Investigation of thermodynamic parameters of cetylpyridinium bromide sorption onto ZSM-5 and natural clinoptilolite, J. Chem. Thermodynamics 36 (2004) 95-100.

[29]. S. Paria, K.C. Khilar, A review on experimental studies of surfactant adsorption at the hydrophilic solid-water interface, Adv. Colloid Interface Sci. 110 (2004) 75-95.

[30] R. Atkin, V. S. J. Craig, S. Biggs, Adsorption kinetics and structural arrangements of cetylpyridinium bromide at the silica-aqueous interface, Langmuir, 17 (2001) 6155-6163. 


\section{Captions of figures and tables}

Fig. 1. Effect of $\mathrm{CP}^{+}$concentration on the turbidity of the electrolytic medium during EC in $0.1 \mathrm{M} \mathrm{NaCl}$ (aluminum electrodes; I = 0.2 A).

Fig. 2. Effect of $\mathrm{CP}^{+}$concentration on the $\mathrm{pH}$ variation during $\mathrm{EC}$ in $0.1 \mathrm{M} \mathrm{NaCl}$ (aluminum electrodes; I = $0.2 \mathrm{~A}$ ).

Fig. 3. Variation of $\mathrm{CP}^{+}$concentration during $\mathrm{EC}$ in $0.1 \mathrm{M} \mathrm{NaCl}$ (aluminum electrodes; $\mathrm{I}=$ $0.2 \mathrm{~A})$.

Fig. 4. Cyclic voltammograms of $\mathrm{CP}^{+}$(glassy carbon electrode; scan rate of $100 \mathrm{mV} / \mathrm{s}$; the increasing currents correspond to $0.6,1.2,2.4$ and $3 \mathrm{mM} \mathrm{CP}^{+}$in $0.1 \mathrm{M} \mathrm{NaCl}$ solution).

Fig. 5. Scheme of the electrochemical behavior of $\mathrm{CP}^{+}$in $0.1 \mathrm{M} \mathrm{NaCl}$ solution at a glassy carbon electrode.

Fig. 6. Effect of the cathode on the abatement of $\mathrm{CP}^{+}$during $\mathrm{EC}$ in $0.1 \mathrm{M} \mathrm{NaCl}$ solution (aluminum anode; cathodes are specified in the figure; $\mathrm{I}=0.2 \mathrm{~A}$ ).

Fig. 7. Variation of $\mathrm{pH}$ during the phosphate-assisted $\mathrm{EC}(0.1 \mathrm{M} \mathrm{NaCl}$ buffered by $0.1 \mathrm{M}$ $\mathrm{Na}_{2} \mathrm{HPO}_{4}+0.1 \mathrm{M} \mathrm{NaH}_{2} \mathrm{PO}_{4}$; aluminum electrodes; I = $\left.0.2 \mathrm{~A}\right)$.

Fig. 8. Variation of $\mathrm{CP}^{+}$concentration during the phosphate-assisted $\mathrm{EC}(0.1 \mathrm{M} \mathrm{NaCl}$ buffered by $0.1 \mathrm{M} \mathrm{Na}_{2} \mathrm{HPO}_{4}+0.1 \mathrm{M} \mathrm{NaH}_{2} \mathrm{PO}_{4}$; aluminum electrodes; I = $0.2 \mathrm{~A}$ ).

Fig. 9.Adsorption kinetics of $\mathrm{CP}^{+}$onto (a1) $\left(\mathrm{AlPO}_{4}\right)_{\mathrm{C}}(\mathrm{b} 1)\left(\mathrm{AlPO}_{4}\right)_{\mathrm{E}}$ and adsorption isotherm onto (a2) $\left(\mathrm{AlPO}_{4}\right)_{\mathrm{C}}(\mathrm{b} 2)\left(\mathrm{AlPO}_{4}\right)_{\mathrm{E}}$ at $22^{\circ} \mathrm{C}$ and $\mathrm{pH} 7.9$

Fig. 10. Adsorption kinetic (a) and isotherm adsorption (b) of $\mathrm{CP}^{+}$onto alumina modified by adsorbed phosphate at $22^{\circ} \mathrm{C}$ and $\mathrm{pH} 6.9$.

Table 1. Second-order kinetic parameters for the removal of $\mathrm{CP}^{+}$by $\left(\mathrm{AlPO}_{4}\right)_{\mathrm{E}}$, and $\left(\mathrm{AlPO}_{4}\right)_{\mathrm{C}}$ at different initial concentrations of $\mathrm{CP}^{+}$. 


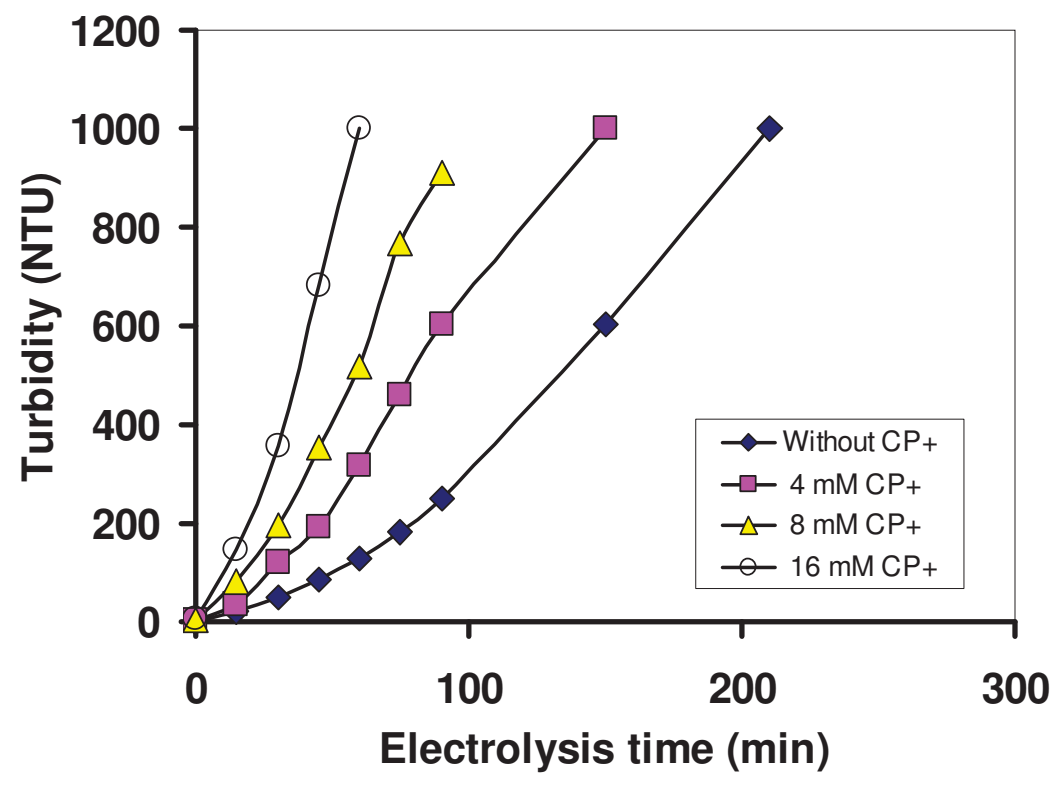

Fig. 1 . 


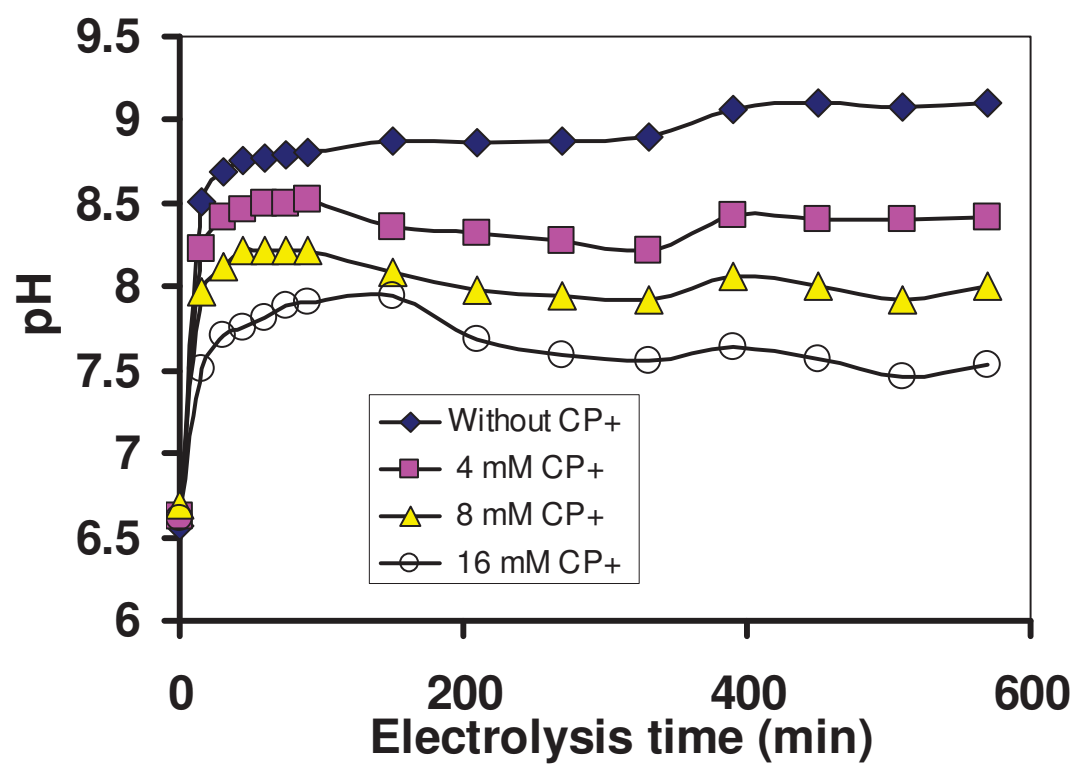

Fig. 2. 


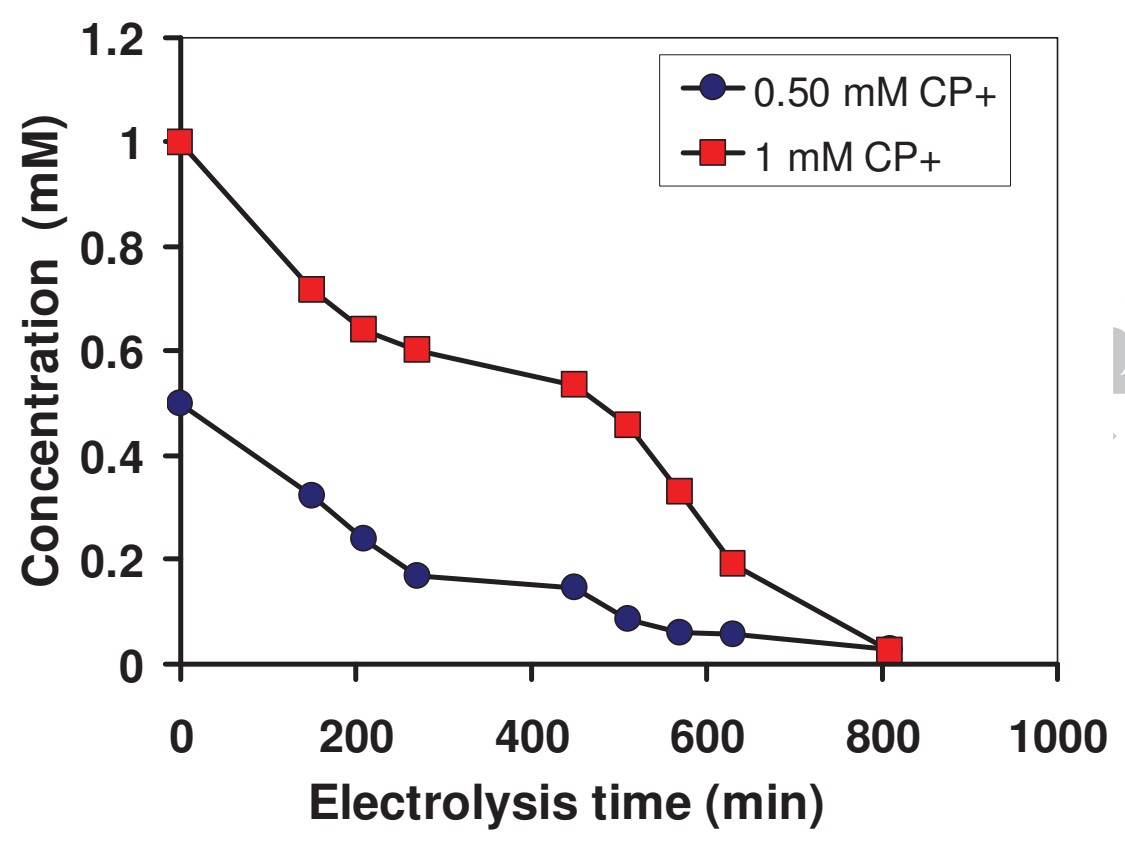

Fig. 3. 


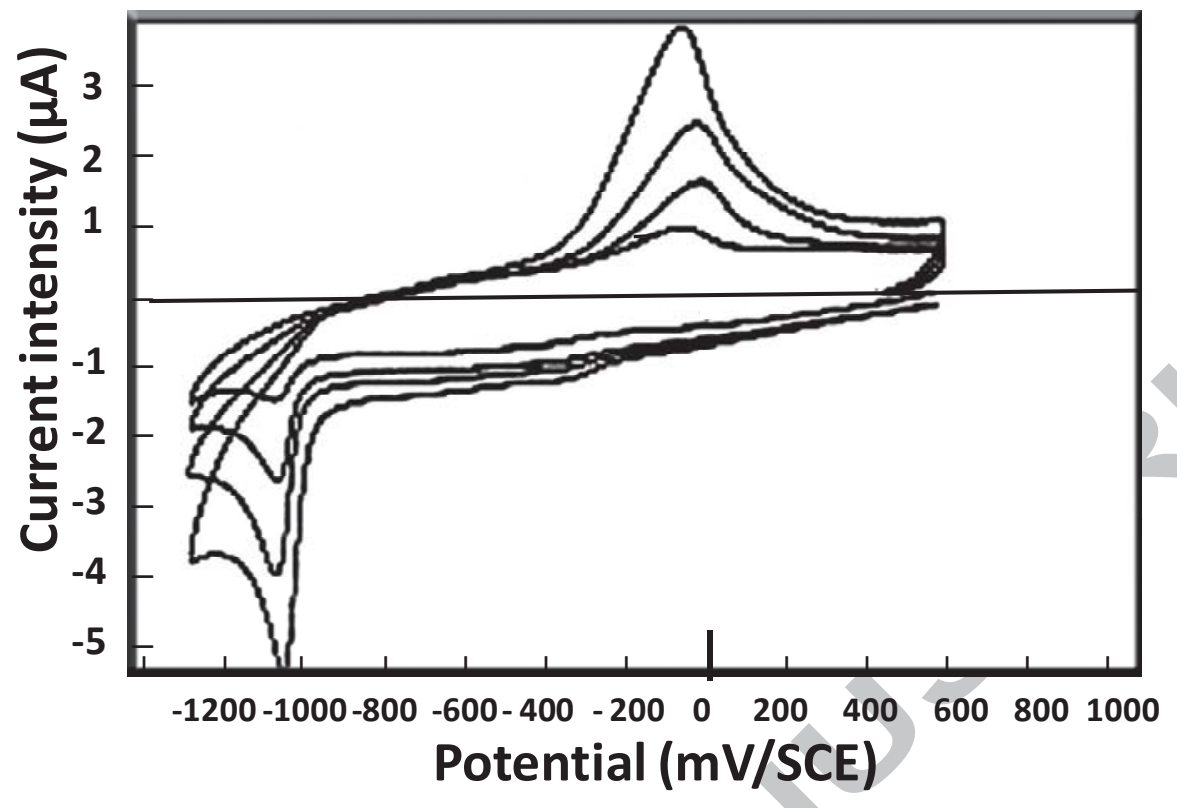

Fig. 4. 


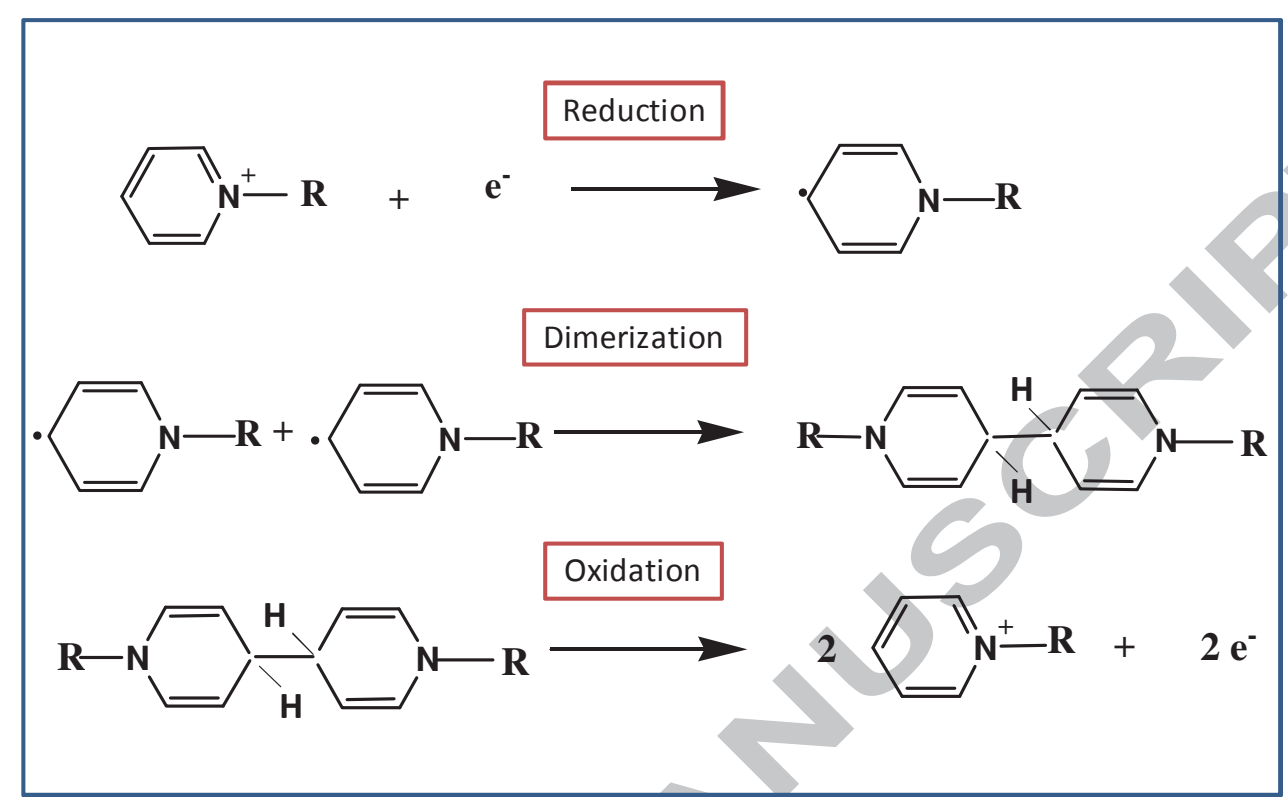

Fig. 5. 


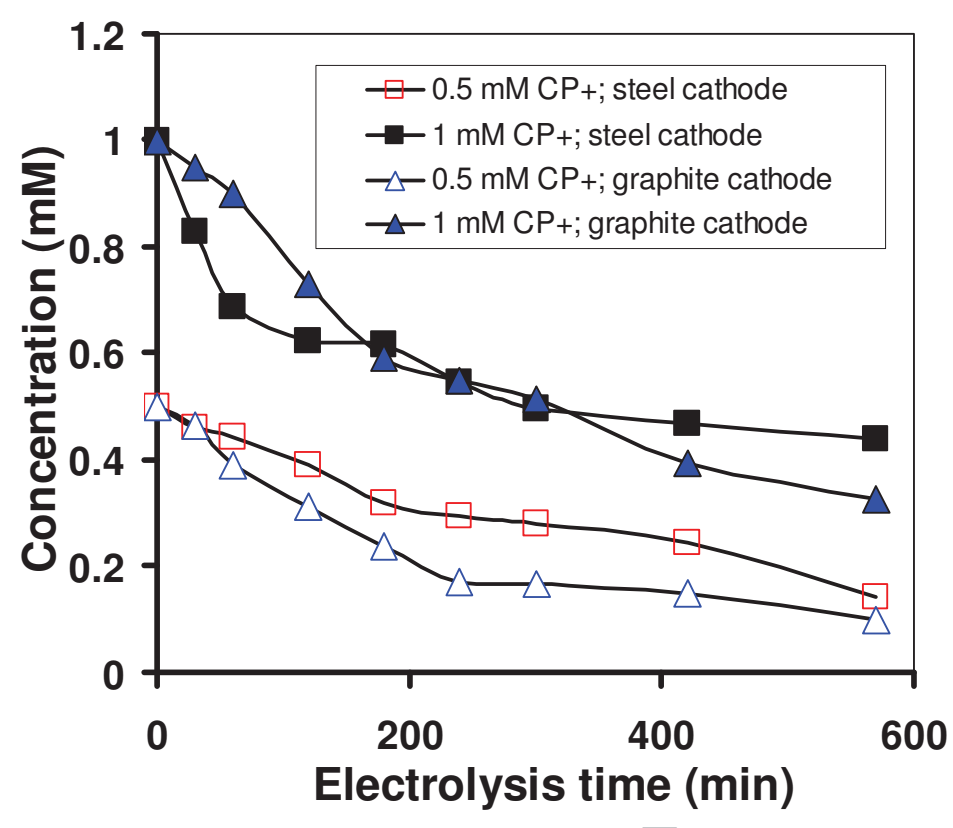

Fig. 6. 


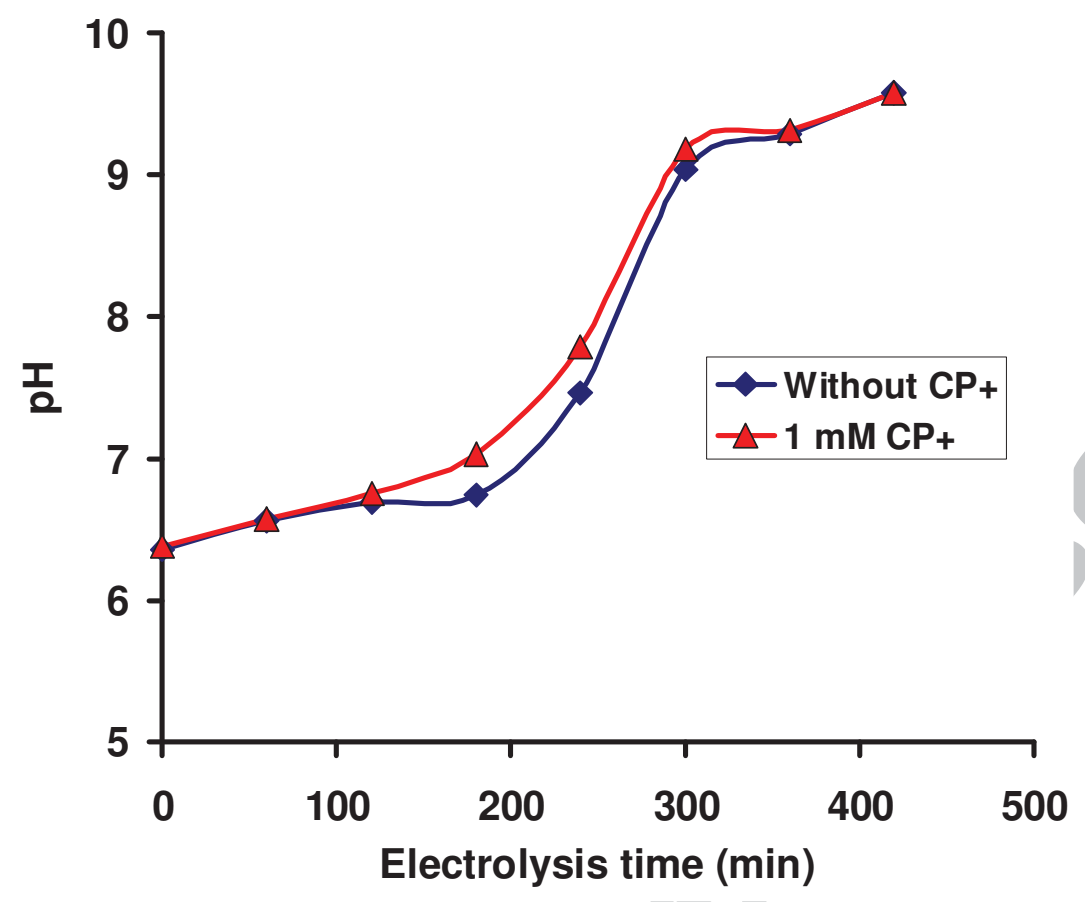

Fig. 7. 


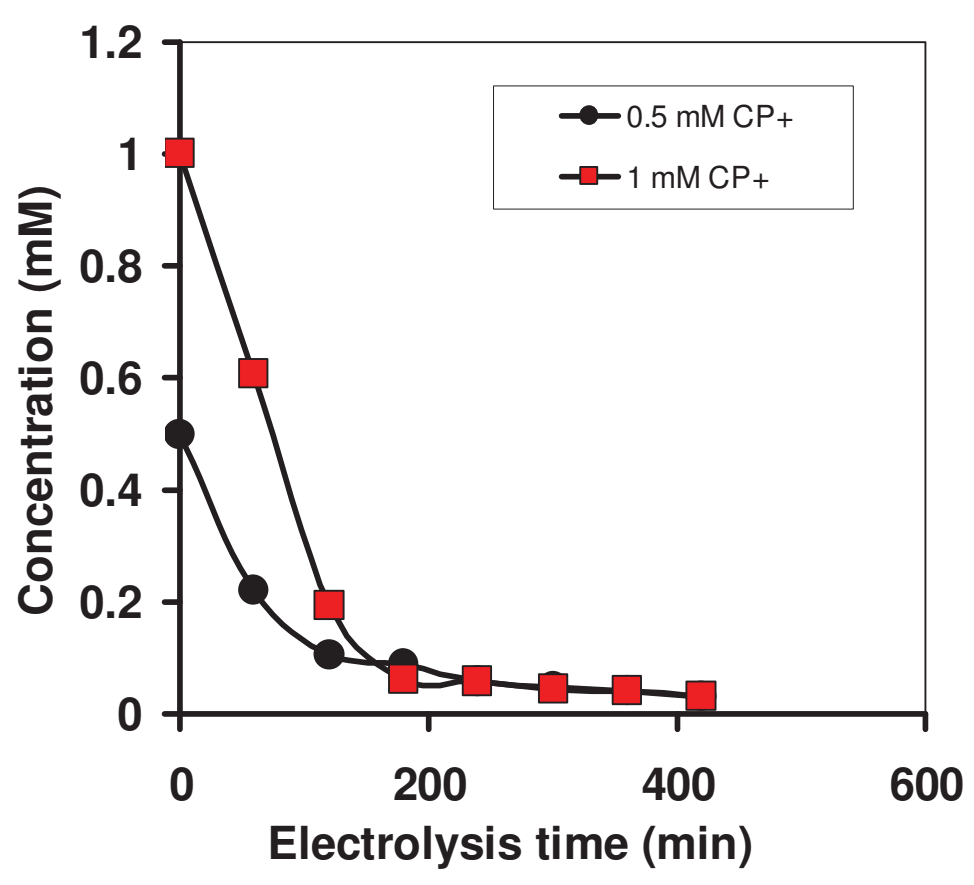

Fig. 8. 

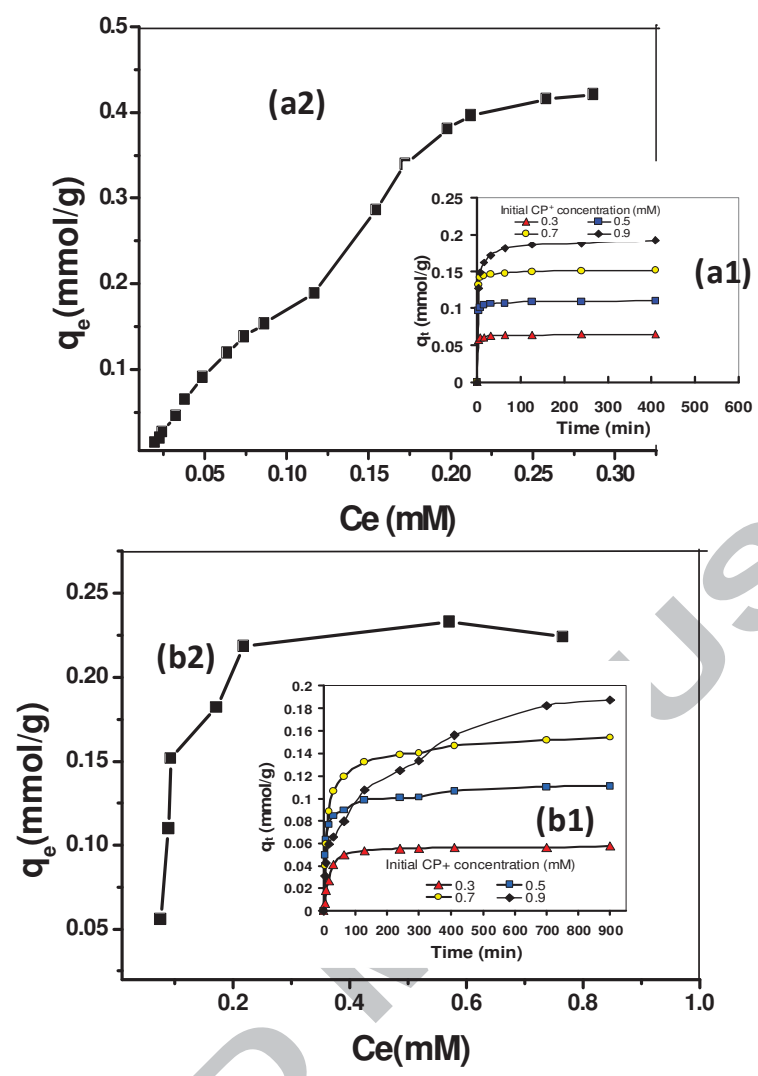

Fig. 9.Adsorption kinetics of $\mathrm{CP}^{+}$onto $(\mathrm{a} 1)\left(\mathrm{AlPO}_{4}\right)_{\mathrm{C}}(\mathrm{b} 1)\left(\mathrm{AlPO}_{4}\right)_{\mathrm{E}}$ and adsorption isotherm onto (a2) $\left(\mathrm{AlPO}_{4}\right)_{\mathrm{C}}(\mathrm{b} 2)\left(\mathrm{AlPO}_{4}\right)_{\mathrm{E}}$ at $22^{\circ} \mathrm{C}$ and $\mathrm{pH} 6.9$ 


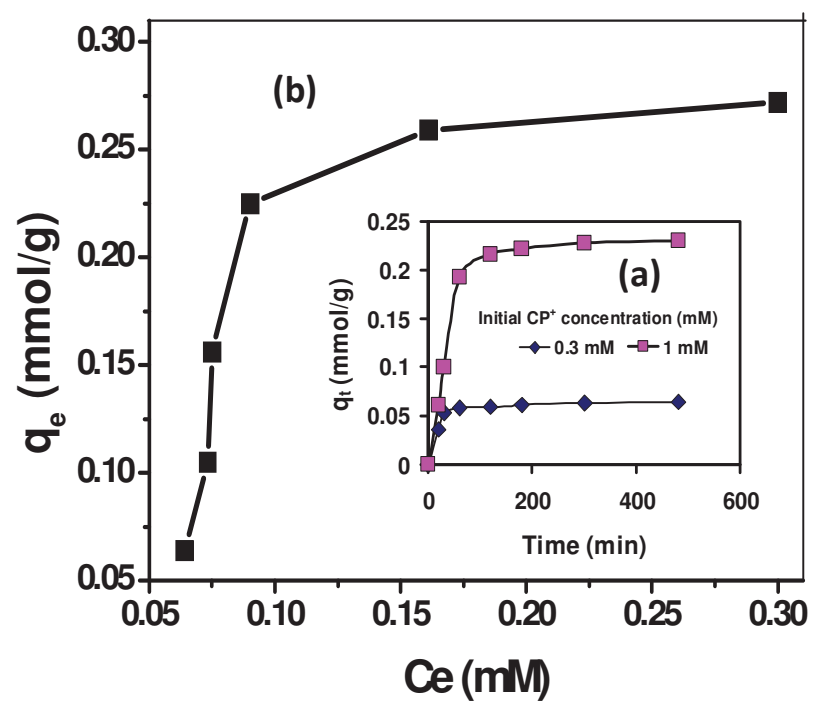

Fig. 10. Adsorption kinetic (a) and isotherm adsorption (b) of $\mathrm{CP}^{+}$onto alumina modified by adsorbed phosphate at $22^{\circ} \mathrm{C}$ and $\mathrm{pH} 6.9$. 


\section{Revised table with all modifications}

Table 1. Second order kinetic parameters for the removal of $\mathrm{CP}^{+}$by $\left(\mathrm{AlPO}_{4}\right)_{\mathrm{E}}$ and $\left(\mathrm{AlPO}_{4}\right)_{\mathrm{C}}$ at different initial concentrations of $\mathrm{CP}^{+}$.

\begin{tabular}{cccccc}
\hline & $\begin{array}{c}\text { Initial } \\
\text { concentration } \\
\text { Adsorbent }\end{array}$ & \multicolumn{4}{c}{ Pseudo second } \\
\cline { 3 - 6 } & of CP $\mathrm{q}^{+}(\mathrm{mM})$ & $\begin{array}{c}\mathrm{q}(\mathrm{exp}) \\
(\mathrm{mmol} / \mathrm{g})\end{array}$ & $\begin{array}{c}\mathrm{q}_{\mathrm{e}}(\mathrm{calc}) \\
(\mathrm{mmol} / \mathrm{g})\end{array}$ & $\begin{array}{c}\mathrm{k}_{2} \\
(\mathrm{~g} / \mathrm{mmol} \mathrm{min})\end{array}$ & $\mathrm{R}^{2}$ \\
\hline \multirow{3}{*}{$\left(\mathrm{AlPO}_{4}\right)_{\mathrm{E}}$} & 0.3 & 0.0465 & 0.0580 & 0.9205 & 0.9994 \\
& 0.5 & 0.1000 & 0.1112 & 0.6370 & 0.9991 \\
& 0.7 & 0.1410 & 0.1554 & 0.3604 & 0.9994 \\
& 0.9 & 0.1810 & 0.1949 & 0.0693 & 0.9804 \\
\hline \multirow{3}{*}{$\left(\mathrm{AlPO}_{4}\right)_{\mathrm{C}}$} & 0.3 & 0.0515 & 0.0647 & 16.63 & 1 \\
& 0.5 & 0.1105 & 0.1103 & 7.499 & 1 \\
& 0.7 & 0.1540 & 0.1520 & 4.947 & 1 \\
& 0.9 & 0.1870 & 0.1925 & 1.555 & 0.999 \\
\hline
\end{tabular}

\section{Revised table}

Table 1. Second order kinetic parameters for the removal of $\mathrm{CP}^{+}$by $\left(\mathrm{AlPO}_{4}\right)_{\mathrm{E}}$ and $\left(\mathrm{AlPO}_{4}\right)_{\mathrm{C}}$ at different initial concentrations of $\mathrm{CP}^{+}$

\begin{tabular}{cccccc}
\hline & \multirow{2}{*}{$\begin{array}{c}\text { Initial } \\
\text { Adsorbent }\end{array}$} & \multicolumn{4}{c}{ Pseudo second } \\
\cline { 3 - 6 } & of $\mathrm{CP}^{+}(\mathrm{mM})$ & $\begin{array}{c}\mathrm{q}_{\mathrm{e}}(\mathrm{exp}) \\
(\mathrm{mmol} / \mathrm{g})\end{array}$ & $\begin{array}{c}\mathrm{q}_{\mathrm{e}}(\mathrm{calc}) \\
(\mathrm{mmol} / \mathrm{g})\end{array}$ & $\begin{array}{c}\mathrm{k}_{2} \\
(\mathrm{~g} / \mathrm{mmol} \mathrm{min})\end{array}$ & $\mathrm{R}^{2}$ \\
\hline \multirow{3}{*}{$\left(\mathrm{AlPO}_{4}\right)_{\mathrm{E}}$} & 0.3 & 0.0465 & 0.0580 & 0.9205 & 0.9994 \\
& 0.5 & 0.1000 & 0.1112 & 0.6370 & 0.9991 \\
& 0.7 & 0.1410 & 0.1554 & 0.3604 & 0.9994 \\
& 0.9 & 0.1810 & 0.1949 & 0.0693 & 0.9804 \\
\hline \multirow{3}{*}{$\left(\mathrm{AlPO}_{4}\right)_{\mathrm{C}}$} & 0.3 & 0.0515 & 0.0647 & 16.63 & 1 \\
& 0.5 & 0.1105 & 0.1103 & 7.499 & 1 \\
& 0.7 & 0.1540 & 0.1520 & 4.947 & 1 \\
& 0.9 & 0.1870 & 0.1925 & 1.555 & 0.999 \\
\hline
\end{tabular}


Graphical abstract

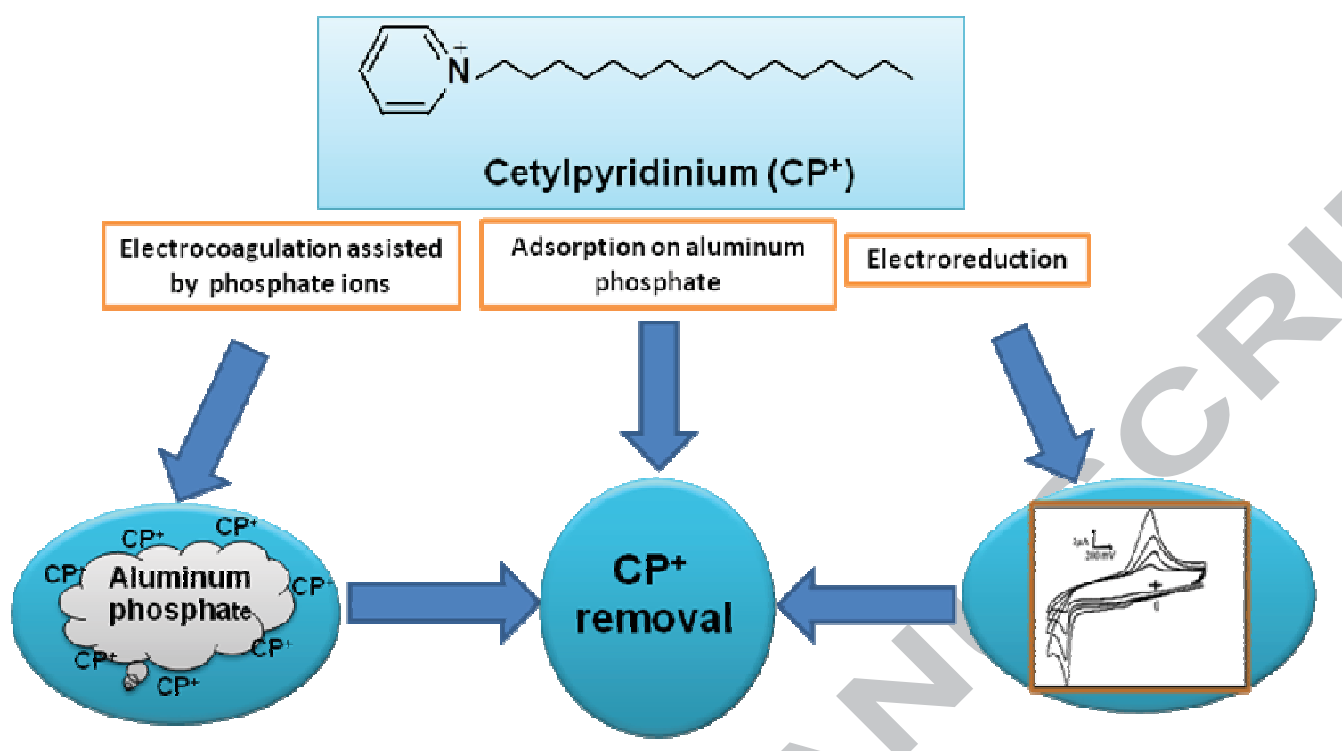




\section{Highlights}

The electrocoagulation treatment of cetylpyridinium $\left(\mathrm{CP}^{+}\right)$was investigated. $\mathrm{CP}^{+}$abatement involved adsorption and electroreduction.

More efficient $\mathrm{CP}^{+}$removal was observed in the presence of phosphate ions. Alumina modified by adsorbed phosphate improves the $\mathrm{CP}^{+}$adsorption. 
$q_{t}=\frac{\left(C_{0}-C_{t}\right) \mathrm{V}}{m}$
$q_{t}=\frac{\left(C_{0}-C_{e}\right) V}{m}$

(2)

$A l \rightarrow A l^{3+}+3 e^{-}$

(3)

$3 \mathrm{H}_{2} \mathrm{O}+3 \mathrm{e}^{-} \rightarrow \frac{3}{2} \mathrm{H}_{2}+3 \mathrm{OH}^{-}$

$2 \mathrm{Al}^{3+}+6 \mathrm{OH}^{-} \rightarrow \mathrm{Al}_{2} \mathrm{O}_{3} \cdot x \mathrm{H}_{2} \mathrm{O}+(3-x) \mathrm{H}_{2} \mathrm{O}(x=0,1,2$ or 3$)$

$2 \mathrm{Al}+6 \mathrm{H}_{2} \mathrm{O} \rightarrow 3 \mathrm{H}_{2}+\mathrm{Al}_{2} \mathrm{O}_{3} \cdot x \mathrm{H}_{2} \mathrm{O}+(3-x) \mathrm{H}_{2} \mathrm{O}(x=0,1,2$ or 3$)$

$\mathrm{Al}+3 \mathrm{H}_{2} \mathrm{O}+\mathrm{Cl}^{-} \rightarrow \frac{3}{2} \mathrm{H}_{2}+\mathrm{Al}(\mathrm{OH})_{2} \mathrm{Cl}+\mathrm{OH}^{-}$

$2 \mathrm{CP}^{+}+2 e^{-} \rightarrow(\mathrm{CP})_{2}$

$\mathrm{Al}^{3+}+\mathrm{H}_{2} \mathrm{PO}_{4}^{-} \rightarrow \mathrm{AlPO}_{4}+2 \mathrm{H}^{+}$

$\mathrm{H}_{2} \mathrm{PO}_{4}{ }^{-}+\mathrm{OH}^{-} \rightarrow \mathrm{HPO}_{4}{ }^{2-}+\mathrm{H}_{2} \mathrm{O}$

$\mathrm{Al}+2 \mathrm{H}_{2} \mathrm{PO}_{4}{ }^{-} \rightarrow \mathrm{AlPO}_{4}+\frac{3}{2} \mathrm{H}_{2}+\mathrm{HPO}_{4}{ }^{2-}$

$\mathrm{Al}+3 \mathrm{H}_{2} \mathrm{O} \rightarrow \mathrm{Al}(\mathrm{OH})_{3}+\frac{3}{2} \mathrm{H}_{2}$

$\mathrm{Al}(\mathrm{OH})_{3}+\mathrm{H}_{2} \mathrm{PO}_{4}^{-} \rightarrow \mathrm{AlPO}_{4}+2 \mathrm{H}_{2} \mathrm{O}+\mathrm{OH}^{-}$

$\mathrm{Al}+2 \mathrm{H}_{2} \mathrm{PO}_{4}{ }^{-} \rightarrow \mathrm{AlPO}_{4}+\frac{3}{2} \mathrm{H}_{2}+\mathrm{HPO}_{4}{ }^{2-}$

$\log \left(q_{e}-q_{t}\right)=\log q_{e}-\frac{k 1 t}{2.303}$

$\frac{t}{q_{t}}=\frac{1}{k_{2} q_{e}^{2}}+\frac{t}{q_{e}}$

(16) 